\title{
Ybビームコリメート光源安定化用共振器の開発
}

\author{
傳田 晟矢，藤原 昇平，畑中 昌平，大向 隆三 \\ 埼玉大学教育学部 ( テ338-8570 埼玉県さいたま市桜区下大久保255)
}

\section{Development of Stable Optical Cavity for Controlling the Light Source to Collimate Yb Beam}

\author{
Seiya DENDA, Syohei FUJIWARA, Syohei HATANAKA and Ryuzo OHMUKAI \\ Department of Physics, Faculty of Education, Saitama University, 255 Shimo-okubo, Sakura-ku, Saitama City, Saitama 338-8570
}

(Received July 24, 2015)

\begin{abstract}
Stabilizing the resonance frequency of an optical cavity was achieved to obtain a reference signal for the 399-nm light source used for collimating a $\mathrm{Yb}$ atomic beam. We attempted cavity control to compensate for laser power by dividing the transmitted light intensity of the cavity by the monitor signal intensity of an incident optical power. As a result, the stability of the resonance frequency for 780-nm light was almost $0.5 \mathrm{MHz}$, which continued for more than 2 hours. This stabilization was maintained until the incident optical power was decreased to $10 \%$ of the initial power. With our technique, highly stable 399$\mathrm{nm}$ light is expected to be generated which enables us to achieve high-performance atomic nanofabrication using $\mathrm{Yb}$ atoms.
\end{abstract}

Key Words: Fabry-Perot cavity, Atom lithography, Ytterbium, Collimation, Optical molasses

1. はじめに

狭帯域で周波数可変のコヒーレント光を発生させる技 術の進歩により，レーザー光を利用して原子の運動を制 御する研究が大きく進展した ${ }^{1)}$ 。我々はこの技術を用い て基板上に微細な周期構造物を作製する原子リソグラ フィー ${ }^{2)}$ の研究に取り組んできた。その結果, オーブン 温度 $1000 \mathrm{~K}$ で発生させたイッテルビウム $(\mathrm{Yb})$ の熱原子 ビームを原子ソースとして双極子力で原子をチャンネリ ングし, 約30分をかけてシリコン基板上へYb原子を堆 積させ, 周期 $200 \mathrm{~nm}$ の平行な線状パターンを作製する ことに成功した ${ }^{3)}$. $\mathrm{Yb}$ 原子は運動制御に必要な399 $\mathrm{nm}$ 光 を市販のレーザーを駆使して得られることに加え，Yb ビームのモノベロシティ化・同位体選別 ${ }^{4-6)}$ や量子縮退 状態の達成7) などレーザー光による様々なハンドリング 技術が確立されている。 また，真空槽から $\mathrm{Yb}$ の微細構 造物を空気中に出しても原子間力顕微鏡でそれを観察で きる. Ybは電気伝導度を持つので微細回路の配線ワイ ヤーにも使える。このようにYbはこの種の実験におい て有望な材料物質である。当該技術の実用化に向けて, 今までよりも高い分解能での細線描画や細線間隔の チューナブル化 ${ }^{8}$ などが当面の課題となるが, それには 原子ソースとなる熱原子ビームの横広がりを可能な限り 抑制することが必須である ${ }^{9)}$. 熱原子ビームのコリメー ションは 1 次元光モラセスに通して横方向に冷却するこ とで行うので, この1次元光モラセスで用いるコヒーレ ント光の周波数を原子堆積時間中一定に保つための工夫
が必要である。

そこで我々はこのコリメーションに使う $399 \mathrm{~nm}$ 光を 発生させるレーザー光源において，その発振周波数を安 定化するための基準となる参照信号を高安定に供給する 共振器の開発を行った。 具体的には, $399 \mathrm{~nm}$ と780 nm の2波長で高いフィネスを持つ共振器を用意し，そこへ 周波数の安定した $780 \mathrm{~nm}$ 光を入射し, 共振器内で780 nm光が共鳴状態を保つように共振器長を制御すること によってその共振器の共鳴周波数を安定化した。そこか ら安定な399 nm光用参照信号を得る。一般にレーザー の発振周波数を外部に設けた共振器を利用して安定化す る方法は, 共振器で使用するミラーの反射率を様々な波 長に対して指定できるので汎用性が高い ${ }^{10)}$ 。 また，原子 の遷移周波数にロックしたレーザー光源で共振器の共鳴 周波数を安定化する方法と組み合わせ，いわゆるトラン スファー共振器を作れば，そこから得られる参照信号の 安定度を非常に高くできる ${ }^{11)}$. 本研究では780 nmレー ザー光源の発振周波数を原子の吸収信号を使って安定化 することはしなかったが, この波長域に吸収を持つルビ ジウム $(\mathrm{Rb})$ の飽和吸収スペクトルから半導体レーザー の発振周波数を安定化する技術は多くの実施例がある ${ }^{12)}$ ので，そのように改良することは特に支障なく実現でき ると考えられる。Y Ybビームのコリメーションに向けて, ここで達成すべき共振器の安定化性能を次の通りとし た。まず，現在のところ原子の堆積に30分を要している こと, 原子オーブンの温度をもう少し下げて真空装置へ の負担を今よりも軽減した条件で原子堆積に臨みたいこ 
となどから，2時間以上はこの共振器の共鳴周波数が安 定化され続けていなければならない。ただし，コリメー ションで利用する $\mathrm{Yb}$ の遷移 $\left({ }^{1} \mathrm{~S}_{0}-{ }^{1} \mathrm{P}_{1}\right)$ の自然幅は $28 \mathrm{MHz}$ と比較的広いので, この共振器の安定度は入射 $780 \mathrm{~nm}$ 光 に対して1.0 MHzを目標とした。これは単純に波長の比 だけから $399 \mathrm{~nm}$ 光の参照信号安定度として換算すると $2.0 \mathrm{MHz}$ になる。共振器長制御のためのロッキングポイ ントは, 共振器の780 nm透過光強度を反映した信号電 圧から一定の直流電圧を差し引いて発生させた。この方 法では差し引く電圧值を変えてロッキングポイントを調 節できるほか, 共振器長や入射光の周波数を変調する必 要がなくなり比較的簡単な電子回路構成や光学配置で ロッキングポイントを設定できる。 ただし，共振器への 入射光パワーが変動した時にロッキングポイントがシフ トするという欠点があるので，本研究ではこれを解消す る工夫を加えた。これは，直接的には共振器へ入射する $780 \mathrm{~nm}$ 光のパワー変動が安定化制御時における共振器の 共鳴周波数へ及ぼす影響を補償する試みであるが, 将来 的にこの共振器で制御対象とする399 $\mathrm{nm}$ 光の周波数安 定化の段階で効果的である。実際， $399 \mathrm{~nm}$ 光は単一周 波数で発振するチタンサファイアレーザー光のSHGから 得られる ${ }^{3)}$ が，ここではレーザーのリング型共振器や高 効率な $\mathrm{SHG}$ 発生のための外部共振器などを使用している ため，実験中に $399 \mathrm{~nm}$ 光パワーの低下が見られた。上 記の機能を付与できれば，このような変化が原子堆積中 に生じてもYbビームの最適なコリメーション条件を維 持し続けられるので, 所望の原子パターン描画の実現に 貢献できる.

\section{2. 実験装置及び配置}

今回製作する399 $\mathrm{nm}$ 光源安定化用共振器として次の 通り設計し組み立てた。構造は共焦点型ファブリー・ペ ロー共振器とし，共振器に用いる2枚のミラーを波長399 $\mathrm{nm}$ と $780 \mathrm{~nm}$ の両方で反射率 $97 \%$, 凹面の曲率半径は300 $\mathrm{mm}$, ミラー間距離も $300 \mathrm{~mm} に し た 。$ 胴体部はスーパー インバー製の中空円筒 (外径 $15 \mathrm{~mm}$, 内径 $9 \mathrm{~mm}$, 長さ $283 \mathrm{~mm}$ ) と, 同じく中空円筒の形をしたピエゾ素子(Piezomechanik製 HPSt 150/14 - 10/12) からなる.このピエゾ 素子に適切な電圧を印加して共振器長を制御し, 共振器 の共鳴周波数を安定化させる。この共振器の設計上の Free Spectral Rangeは250 MHz，フィネスは51.6, フリン ジピークの半值全幅は $4.8 \mathrm{MHz}$ である.

全体の実験配置をFig. 1に示す。光源には発振波長が $780 \mathrm{~nm}$ の外部共振器型半導体レーザー (ECLD: NewFocus Model 6013)を用いた。 この光源は発振周波数を安定化 するためにLDへの注入電流やLDを含めた共振器全体の 温度の安定化, 装置全体のハウジングなどの工夫がなさ れており，ここからパワーが9 $\mathrm{mW}$ ，スペクトル線幅 $300 \mathrm{kHz}$ 以下のシングルモード光が出力される. この出 力を光アイソレーターとNDフィルタ1 $(\mathrm{NDF} 1)$ に通した あとハーフミラーで2つに分け, 一方はNDフィル夕2 (NDF2)を通してフォトダイオード1(PD1)で受けて共振

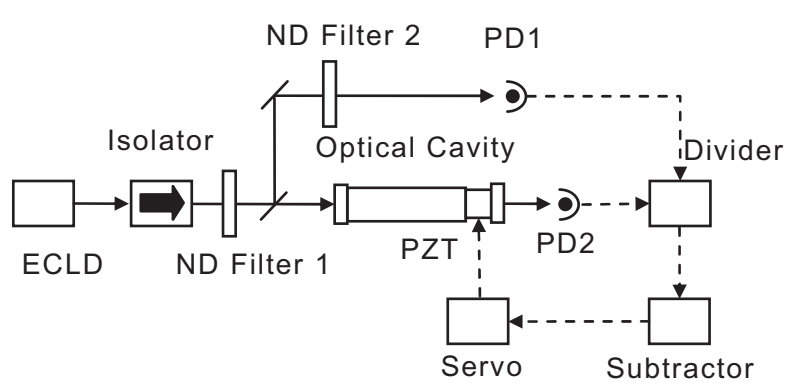

Fig. 1 Experimental setup. (ECLD: External cavity laser diode, PD: Photodiode)

器への入射光パワーのモニタ信号電圧として, 他方は共 振器へ通してからフォトダイオード2(PD2)で受けて透 過光信号電圧として検出した。 NDF2の透過率はPD1か ら得られるパワーモニタ信号電圧が飽和しないよう適切 に調節した。 そのあと, 共振器の透過光信号電圧をモ二 夕信号電圧で除算した。除算出力信号電圧から一定の電 圧 (共振器のフリンジピークの半分の電圧)を減算し, 共 振器内で780 $\mathrm{nm}$ 光の共鳴を維持できるように共振器長 を制御するためのロッキングポイントを設定した。透過 光信号は共振器への入射光パワーに応じて変化するが, 除算出力信号ならばこの影響を受けないので，これを用 いてロッキングポイントを設定すれば入射光パワーが変 化しても最初に設定したロッキングポイントを変わらず に保つことができる．何らかの理由で制御途中に入射光 パワー変動が発生しても安定して399 nm光用の参照信 号を供給できると期待される。除算器の回路の概略を Fig. 2に示す ${ }^{13)}$. この除算出力信号から誤算信号を得て, これを制御回路に入力した。ここでピエゾ素子に印加す ベきフィードバック信号電圧を発生させる，本実験で使 用したピエゾ素子のストロークは印加電圧範囲 $0 \sim 150 \mathrm{~V}$ で12 $\mu \mathrm{m}$ なので, 安定化制御時にこのストローク長を最 大限活用できるよう，制御回路の出力電圧もこの範囲と 同じに設計した。

\section{3. 実験結果と考察}

最初に, 組み立てた共振器の性能確認のため, ECLD から得られる波長780 $\mathrm{nm}$ の単一周波数光を共振器へ入 射し, 共振器長を掃引してその透過スペクトルを測定し た．Fig. 3にその結果を示す，2つのフリンジピークの間 隔を $250 \mathrm{MHz}$ とてピークの半值全幅を見積もったとこ

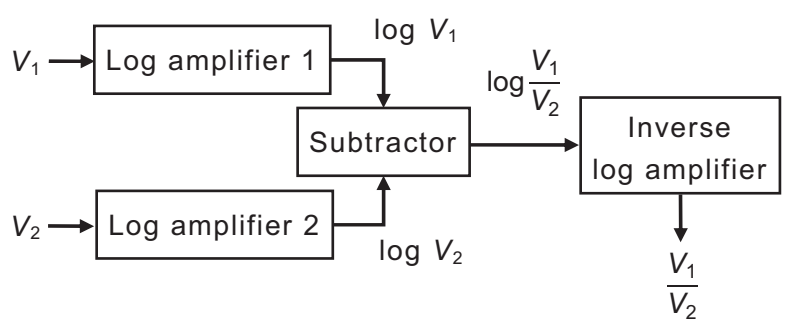

Fig. 2 Block diagram of a divider. 


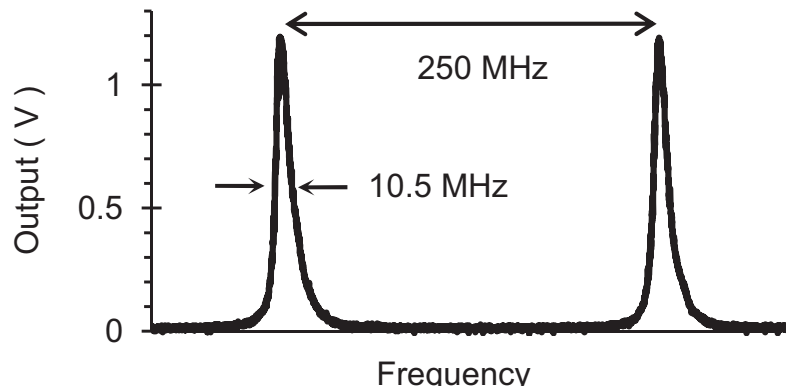

Fig. 3 Transmission spectrum of a cavity.

ろ10.5 MHzであった。設計上の值よりも6 MHz大きな值 となった。 共振器のミラー, 胴体, ピエゾ素子は接着剤 で固定したので，実際のミラー間距離とミラーの曲率半 径との間に生じた差が, 組み立てた共振器のフィネスを 設計值よりも低下させた要因と考えられる。しかし, 当 初目標とした安定度を実現するには影響ないと判断し て、このまま実験を行った。

次に, 除算出力のスペクトルが入射光パワーを減少さ せても変化しないかを確認した. Fig. 1の実験配置で NDF1の透過率を2〜 100\%の範囲で変え, 共振器長を掃 引したときに観測される干渉フリンジを透過出力信号と 除算出力信号の両方で測定した. この結果をFig. 4に示 す。横軸はNDF1の透過率，縦軸は透過率100\%を基準と したフリンジピーク電圧の相対值である。透過光信号か ら得たフリンジピーク電圧は入射光パワーに比例して小 さくなったが，除算出力信号は入射光パワーが当初の 20\%になるまでほぼ一定に保たれた。しかし，10\%未満 になると除算出力のピーク電圧は回復しなくなった。

Table. 1はNDF1の各透過率で除算出力のフリンジピーク 電圧をまとめた結果であるが，これを見ると入射光パ ワーが当初の $20 \%$ に減少するまではピーク電圧は誤差の 範囲内で一致している。10\%よりも低くなるとピーク電 圧は $100 \%$ のそれと比べてわずかに差が生じて小さな值 になり始め, $2 \%$ では $100 \%$ のピーク電圧の7割以下しか 得られなかった。 これは，入射光パワーが当初の $10 \%$ 以下まで減るとモニ夕信号と透過光信号のS/Nが両方と も悪化していくこと, 共振器の透過光信号におけるフリ ンジピーク電圧がバックグラウンド電圧と同程度になる

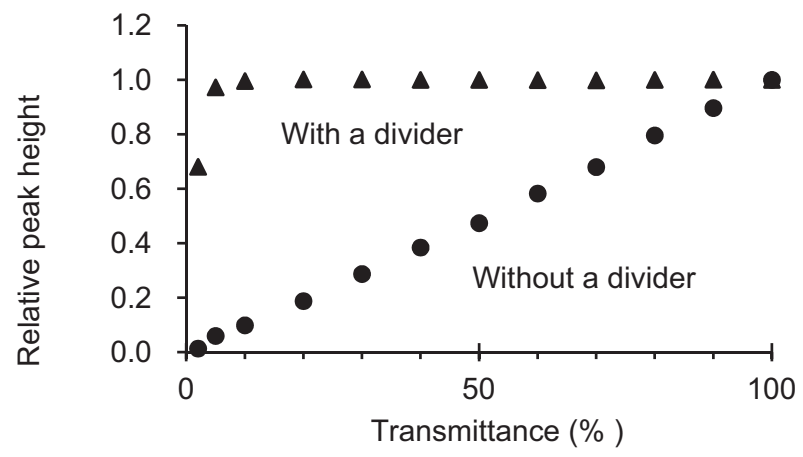

Fig. 4 Fringe peak voltage with and without a divider.
Table 1 Peak voltage of the devided signal.

\begin{tabular}{cccc}
\hline Transmittance (\%) & Peak voltage of the devided signal (V) \\
\hline 100 & 1.190 & \pm & 0.002 \\
90 & 1.191 & \pm & 0.003 \\
80 & $1.190 \pm \pm$ & 0.002 \\
70 & 1.188 & \pm & 0.002 \\
60 & 1.189 & \pm & 0.002 \\
50 & $1.190 \pm \pm$ & 0.002 \\
40 & $1.190 \pm \pm$ & 0.002 \\
30 & $1.192 \pm \pm$ & 0.002 \\
20 & $1.192 \pm \pm$ & 0.002 \\
10 & 1.185 & \pm & 0.002 \\
5 & 1.157 & \pm & 0.003 \\
2 & 0.810 & \pm & 0.002 \\
\hline
\end{tabular}

ことなどが原因である．Fig. 5は実際に測定された共振 器の透過光スペクトルと除算出力スペクトルの一例であ る.ここでは比較しやすくするために透過光信号と除算 出力信号のフリンジピーク電圧がほぼ同じになるように NDF2の透過率を設定した。 NDF1の透過率が100\%と $20 \%$ に抄ける結果を示す。透過スペクトルは入射光パ ワーが $20 \%$ に減少すると $100 \%$ のきと比べてその強度 が大幅に低下しているが, 除算出力のスペクトルではス ペクトルの形状やピークの電圧值が変わっていない．共 振器の透過光スペクトルが半值全幅 $10.5 \mathrm{MHz}$ のローレ ンツ曲線を描くこと, 実際の実験条件に即してNDF1の 透過率100\%のときのフリンジピークの半分の電圧を減 算してロッキングポイントを設定することなどを仮定し て，透過光信号たけを用いて安定化制御を行うときの ロッキングポイントのシフト量を見積もった。その結 果, 入射光パワー減少に伴い徐々にロッキングポイント がシフトし，入射光パワーが当初の $60 \%$ まで減少すると

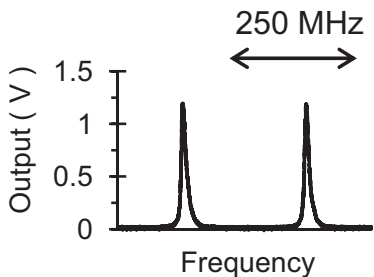

( a ) Transmission spectrum at $100 \%$

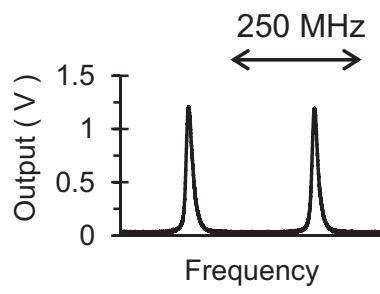

(b) Divided spectrum at $100 \%$

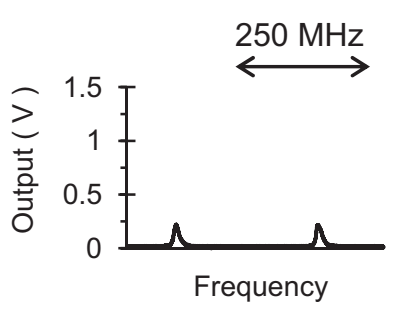

(c) Transmission spectrum at $20 \%$

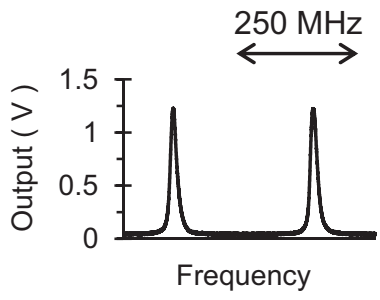

(d) Divided spectrum at $20 \%$
Fig. 5 Transmission spectra and divided spectra when transmittance of ND filter is $100 \%$ and $10 \%$. 
$3 \mathrm{MHz}$ もフトすると見積もられた。当然ながら, 当初 の $50 \%$ 以下まで減少するとロッキングポイントは消失 し，そもそも安定化制御を行うことができなくなる。 こ れに対し，除算出力信号を使ってロッキングポイントを 設定する方法では，入射光パワーが当初の $20 \%$ に減少す るまでロッキングポイントは変動しないと考えてよい。

入射光パワーが当初の $5 \%$ まで低下して除算によりフリ ンジピーク電圧を回復できなくなる場合でも, 上記と同 様に見積もったロッキングポイントのシフト量は 0.13 MHzであった。これらの結果から，除算出力信号を使 うことにより幅広い入射光パワー変動に対して安定した ロッキングポイントを設定できることがわかった。

続いて, 上記の除算出力信号を使って共振器の共鳴周 波数を安定化し, その性能を評価した。 最初はFig. 1の 実験配置でNDF1の透過率を100\%にし，ピエゾ素子へ適 切な直流電圧を印加して780 $\mathrm{nm}$ 光が共振器で共鳴する 状態へ近づけたあと, 制御回路を動作させて共鳴周波数 の安定化を開始した。ロッキングポイントは共振器のフ リンジピークの半分の電圧值に設定した. PD1で測定さ れるパワーモニタ信号, PD2で測定される透過光信号, 除算出力信号, ピエゾ素子に印加される信号 (フィード バック信号)を測定・記録した。制御開始直後から 400 秒間における上記の信号を Fig. 6に, それから2時間後

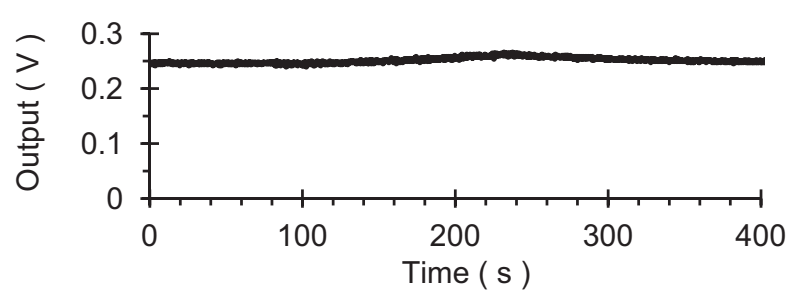

(a)

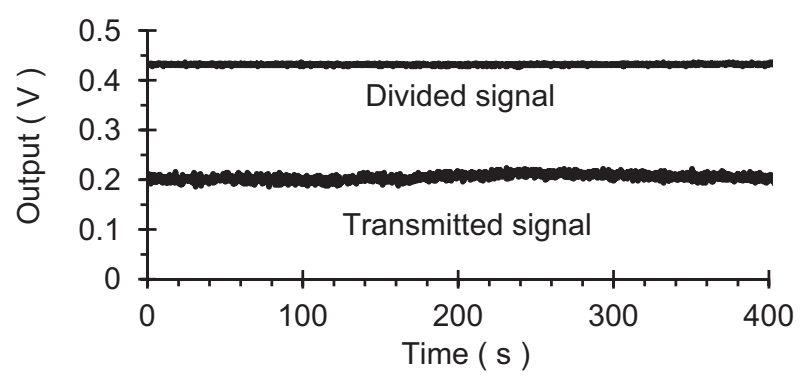

(b)

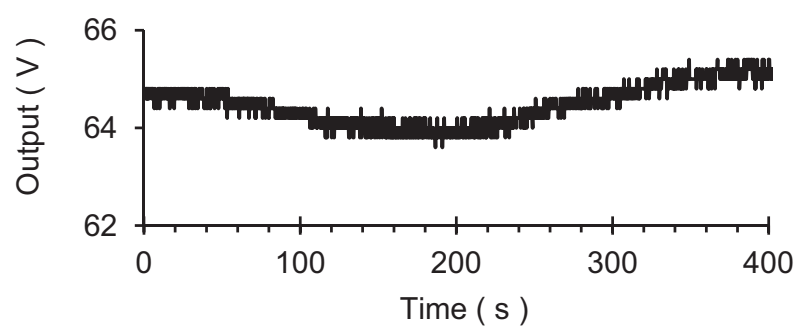

(c)

Fig. 6 Experimental results after the start of control. (a) Power monitor signal, (b) Devided signal and transmitted signal, and (c) Feedback signal.
に測定した除算出力信号と透過光信号をFig. 7に示す. Fig. 6(b) と (c)，Fig. 7を見ると，除算出力信号が一定の 電圧に保たれていることがわかり，この電圧はフリンジ ピークの半分の電圧に相当することも確認した。 フィー ドバック信号電圧も室温などの周囲の環境変化などに 伴って0〜150 Vの範囲内で連続的に変化する信号になっ ていた。これらのことから所望の安定化制御が行われて いることがわかった。また，制御を開始してから2時間 の途中に打除算出力信号はFig. 6(b) と同様であった ので，少なくとも2時間以上にわたり我々の実験室環境 下で共振器の共鳴周波数を安定化したことを確認した。 この制御中における共振器の共鳴周波数の安定度につい ては, Fig. 3で示した透過光スペクトルをパワーモニタ 信号で除算出力したスペクトルを用い, Fig. 6(b) やFig. 7で示した除算出力信号電圧の最小值と最大值から周波 数の変動幅を求めた。 その結果, 制御開始直後400秒間 における共振器の共鳴周波数の変動幅は780 nm光に対 して0.45 MHzとなった。また, 制御開始から2時間経過 した後でもこの值は $0.48 \mathrm{MHz}$ とり, 開始直後とほぼ 同じく0.5 MHz以下の安定度を維持できていた。2時間 経過する途中の除算信号電圧の変動幅もこれらと比べて 変わらなかったので，2時間にわたり $0.5 \mathrm{MHz}$ 以下の安 定度を保つことができた。制御の継続時間，安定度とも 最初に目標とした性能を達成することができた。この $0.45 \mathrm{MHz}$ という安定度を399 nm光用の参照信号の安定 度に単純な波長の比だけで換算すると0.88 MHzになる。

最後に, Fig. 1のNDF1により意図的に共振器への入射 光パワーを減少させ，それにより共鳴周波数の安定化制 御性能がどのような影響を受けるかについて調べた。ま

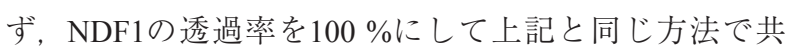
振器の共鳴周波数を安定化したあと, NDF1の透過率を 連続的に減少させた。入射光パワー変動の補償をしない とき(共振器の透過光強度信号からロッキングポイント を設定したとき)の透過光信号電圧, 除算出力信号電圧, パワーモニ夕信号電圧の測定結果をFig. 8(a)に，入射光 パワー変動補償をしたとき(除算出力信号からロッキン グポイントを設定したとき)のそれらの結果をFig. 8(b) に示す，入射光パワー変動を補償しない場合は，入射光 パワーをFig. 8(a) 1)のように減少させたとき安定化制御 中の透過光信号電圧はFig. 8(a) (2)で示したように一定に 保たれていたが, Fig. 8(a) (3)の除算出力信号電圧は徐々 に増加した。つまり，入射光パワー減少に伴いロッキン

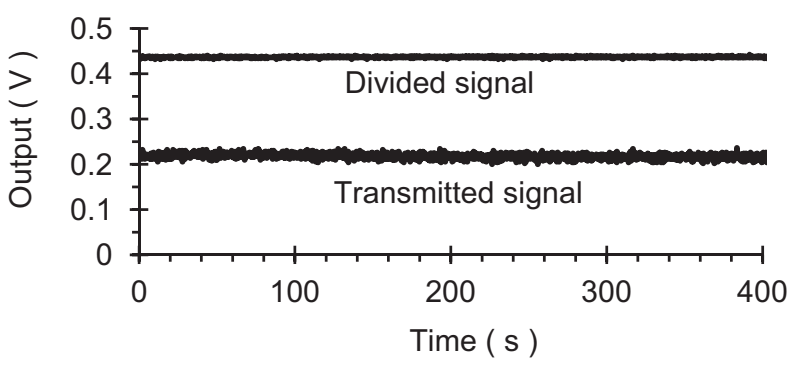

Fig. 7 Experimental results in 2 hours after the start of control. 
( a ) Without a divider

( b ) With a divider

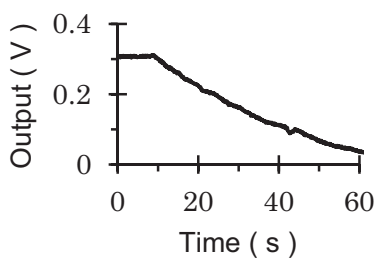

(1) Power monitor signal

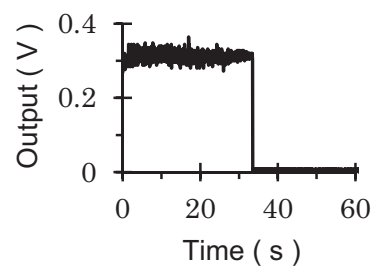

(2) Transmitted signal

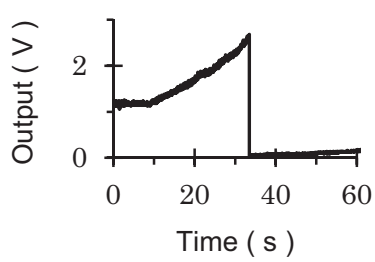

(3) Divided signal

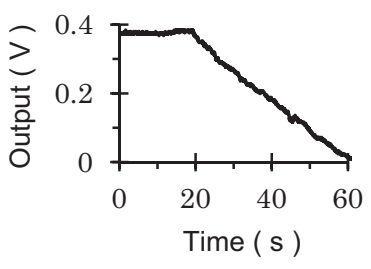

(1) Power monitor signal

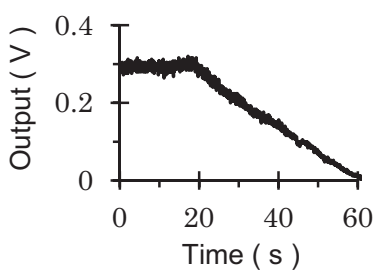

(2) Transmitted signal

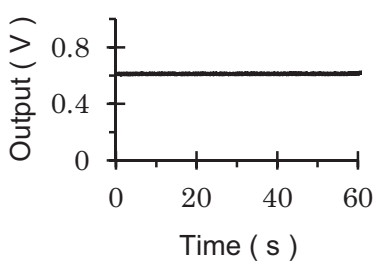

(3) Divided signal

Fig. 8 Experimental results when incident optical power was decreased.

グポイントがフリンジのピークの方へシフトし，そのシ フトに追随しながら共振器の共鳴周波数が制御されてい る。そしてさらに入射光パワーが減少するとついには ロッキングポイントが消失してロックが外れ，その瞬間 に透過光信号電圧と除算出力信号電圧が $0 \mathrm{~V}$ になった。

これに対して入射光パワー変動を補償した場合は, 入射 光パワーをFig. 8(b) (1)のように減少させても, Fig. 8(b) (3)で示した除算出力信号電圧が一定に保たれたままで あった，逆にFig. 8(b) (2)で示した透過光信号のほうが減 少した，これらのことから，この制御では入射光パワー の減少の影響を受けず，ロッキングポイントが一定のま ま共振器の共鳴周波数が安定化されていることがわかっ た。 また, 共振器の安定化制御時における除算出力信号 電圧の変動幅は，入射光パワーを当初の $10 \%$ まで減少さ せるまでの間変化しておらず，780 $\mathrm{nm}$ 光に対する共振 器の共鳴周波数の安定度はこの間ずっと上述の安定度 (0.5 MHz以下)を維持できていると考えられる.

\section{4. まとめ}

共焦点型ファブリー・ペロー共振器を利用して, $399 \mathrm{~nm}$ 光の周波数を安定化させるための高安定な参照信号を発 生させる共振器を開発した。 $399 \mathrm{~nm}$ と $780 \mathrm{~nm}$ の2波長で 高い反射率を持つミラーを使い，共振器長をピエゾ素子

への電圧印加により制御し，入射780 nmレーザー光が 共振器内で共鳴を保つような制御を施した。同時に，入 射光パワーの変動に対して共振器の共鳴周波数がシフト しない工夫として，共振器の透過光信号を共振器への入 射光パワーモニ夕信号で除算し，その信号から共振器長 制御のロッキングポイントを発生させた。実験の結果, 共振器内で780 $\mathrm{nm}$ 光の共鳴状態を 2 時間以上にわたり維 持させることができた。 また，共振器の共鳴周波数を入 射780 nm光に対して0.5 MHz以下の安定度で制御でき た。さらに, 入射780 $\mathrm{nm}$ 光のパワー変動に対しては, 当初の $10 \%$ に減少するまでの間ロッキングポイントのシ フトを $0.13 \mathrm{MHz}$ 以下に抑制することができ，かつ，そ の間共振器の共鳴周波数の安定度は変わらずに維持でき た。これらを単純に足し合わせても，共振器の共鳴周波 数の安定度は入射780 nm光に対して $0.63 \mathrm{MHz}$ となり, 当初の目標を達成できた。この值を単純に波長の比た けから399 nm光用参照信号の安定度として換算すると $1.23 \mathrm{MHz}$ になる。今後はRbの飽和分光を用いた780 nm レーザー光源の発振周波数安定化, $399 \mathrm{~nm}$ 光源に対す るこの共振器を使った周波数安定化の試み, $\mathrm{Ybビーム}$ のコリメーション性能の評価へと進めていく予定である が，実際には空気の屈折率が波長により異なり，さらに 各波長の屈折率が温度や気圧の変化の影響を受ける ${ }^{11,14)}$.

この共振器で安定化した場合の399 nm光の絶対周波数 のずれは温度変化の割合が $20 \mathrm{MHz} /{ }^{\circ} \mathrm{C}$ ，気圧の変化に対 してはー5 MHz/hPaとなる。コリメーション性能を最大 限に発揮するにはこれらの変化を可能な限り抑制する工 夫 (真空槽内あるいはシールした容器内への共振器の配 置など)も将来的に必要になる。

\section{参考文献}

1) 例えば, 嶺重 慎, 高橋 義朗, 田中 耕一郎：光と物理学(京 都大学学術出版会, 2007) p.27.

2) G. Timp, R. E. Behringer, D. M. Tennant, and J. E. Cunningham: Phys. Rev. Lett. 69(1992) 1636.

3) R. Ohmukai, S. Urabe, and M. Watanabe: Appl. Phys. B 77 (2003) 415.

4) M. Watanabe, R. Ohmukai, U. Tanaka, K. Hayasaka, H. Imajo, and S. Urabe: J. Opt. Soc. Am. B 13 (1996) 2377.

5) R. Ohmukai, H. Imajo, K. Hayasaka, U. Tanaka, M. Watanabe, and S. Urabe: Appl. Phys. B 64 (1997) 547.

6) M. Watanabe, R. Ohmukai, H. Imajo, K. Hayasaka, and S. Urabe: Jpn. J. Appl. Phys. 36 (1997) 7189.

7) Y. Takasu, K. Maki, K. Komori, T. Takano, K. Honda, M. Kumakura, T. Yabuzaki, and Y. Takahashi: Phys. Rev. Lett. 91 (2003) 040404.

8) R. Ohmukai, S. Urabe, and M. Watanabe: Sci. Tech. Adv. Mat. 5 (2004) 585.

9) J. J. McClelland: J. Opt. Soc. Am B 12 (1995) 1761.

10) R.W.P. Drever, J.L. Hall, F.V. Kowalski, J. Hough, G.M. Ford, A.J. Munkey, and H. Ward: Appl. Phys. B 31 (1983) 97.

11) E. Riedle, S. H. Ashworth, J. T. Farrell, Jr., and D. J. Nesbitt: Rev. Sci. Instrum. 65 (1994) 42.

12) K. B. MacAdam, A. Steinbach, and C. Wieman: Am. J. Phys. 60 (1992) 1098.

13）岡山努：ダイオード・トランジスタ回路入門(日刊工業新 聞社, 2005年) p.171.

14) S. Uetake, K. Matsubara, H. Ito, K. Hayasaka, M. Hosokawa: Appl. Phys. B 97 (2009) 413. 